\title{
The Kidney of Spiny Mice (Acomys cahirinus): Electron Microscopy of Glomerular Changes Associated with Ageing and Tubular Glycogen Accumulation during Hyperglycemia*
}

\author{
L. Orci, W. Stauffacher, M. Amherdt, R. Piotet, A.E. Renold and Ch. Rouiller \\ Institut d'Histologie et d'Embryologie, Institut de Biochimie Clinique and Clinique Universitaire \\ de Médecine Interne of the University of Geneva, Geneva, Switzerland.
}

Summary. Glomeruli and tubules of the kidney of normoglycemic and diabetic spiny mice were studied with the electron microscope. Progressive thickening of the basement membranes of glomerular capillaries with a concomitant increase in the deposition of basement-membrane-like mesangial matrix occurred with age. Focal hemispherical thickenings of the basement membrane on its epithelial side were observed with increasing frequency in older animals. The plasma membrane of adjacent foot processes exhibited features suggestive of pinocytosis. Collagen fibers in electronlucent areas surrounded by mesangial matrix were regularly seen in animals beyond the age of twelve months. In diabetic animals, the alterations of the glomerular capillary basement membranes and of the mesangial region appeared to be more pronounced but no specific lesions were observed. This negative finding may be related to the relatively short duration of the diabetic state. Measurements of the thickness of glomerular capillary basement membranes showed a significant age-dependent increase in basement membrane width and indicated that this process may be accelerated in diabetic animals. Examination of the renal tubules of diabetic animals showed a characteristic segmental pattern of glycogen storage in epithelial cells with considerable varia. tions in the degree of glycogen infiltration between different segments but also between individual cells of a given segment. The most surprising feature associated with glycogen storage was the occurrence of lysosomes filled with glycogen. The mechanisms responsible for the accumula. tion of glycogen within lysosomes are unknown but may be related to an increase in glycogen turnover in cells actively involved in the reabsorption of glucose or to an impair ment of lysosomal function secondary to diabetes.

Le rein de la souris à piquants (Acomys cahirinus): Etude ultrastructurelle des altérations glomérulaires en fonction de l'âge et de l'accumulation de glycogène dans les tubules au cours de l'hyperglycémie

Résumé. Les glomérules et tubules rénaux de souris à piquants (Acomys cahirinus) normoglycémiques et diabétiques ont été étudiés au microscope électronique. L'épaisseur de la membrane basale des capillaires glomérulaires ainsi que l'espace occupé par la matrice mésan. giale augmentaient progressivement avec l'âge de l'animal. Outre l'épaississement général de la membrane basale, on nota un épaississement focal du côté épithélial. La membrane cytoplasmique des prolongements podocytaires adjacents présentaient des modifications suggérant une pinocytose active. Chez les animaux âgés de plus de douze mois, la matrice mésangiale était régulièroment caractérisée par la présence de lacunes contenant des fibres de collagène. Chez les animaux diabétiques, les altérations capillaires et mésangiales étaient en général plus marquées sans que l'on ait rencontré les lésions typiques du diabète. Ceci pourrait être dû à la durée relativement brève du diabète chez les animaux examinés.

* Supported in part by the Fonds National Suisse de la Recherche Scientifique, Berne, Switzerland (Grants No. 5344 and 4848.3), and by a grant-in-aid through Zyma S.A., Nyon, Switzerland.
L'épaisseur des membranes basales des capillaires glomérulaires augmente progressivement avec l'âge et le diabète pourrait accélérer ce processus. L'examen des tubules rénaux des animaux diabétiques a permis de constater que le degré d'infiltration de glycogène varie de façon caractéristique entre les différents segments tubulaires, mais aussi entre les cellules épithéliales d'un même segment. La présence de lysosomes remplis de glycogène représente l’observation la plus surprenante. Les mécanismes responsables de cette accumulation intralysosomiale de glycogène sont encore inconnus: elle peut résultor de la réabsorption massive de glucose et/ou d'un dérangement de la fonction lysosomiale secondaire à l'état diabétique.

Die Niere der Stachelmaus (Acomys cahirinus): Elektronenmikroskopische Untersuchungen altersbedingter Ver. änderungen der Glomeruli und der tubulären Glykogenspeicherung im Verlauf der Hyperglykämie

Zusammenfassung. Die Glomeruli und Tubuli der Nieren normoglykämischer und diabetischer Stachelmäuse (Acomys cahirinus) wurden untersucht: Die Basalmembranen der Glomeruluskapillaren sowie die Matrix des Mesangiums verdickten sich mit zunehmendem Alter der Tiere; weiterhin ließen sich bei älteren Tieren fokale Verbreiterungen auf der epithelialen Seite der Basalmembran nachweisen, die ultrastrukturell von der letztern nicht zu unterscheiden waren. Die Plasmamembran der angrenzenden Podocytenfüßchen enthielt auf gesteigerte Mikropinocytose hinweisende Vesikel. In der Matrix des Mesangiums von über zwölf Monate alten Tieren fanden sich regelmäßig Lacunen, in denen Kollagenfasern festgestellt wurden. Bei diabetischen Tieren waren die Veränderungen der Basalmembranen und des Mesangiums in der Regel stärker ausgeprägt als bei normoglykämischen; sogenannto typische diabetische Veränderungen wurden aber nicht beobachtet. Dies mag mit der relativ kurzen Dauer des Diabetes der untersuchten. Tiere zusammenhängen. Die Messung der Dicke der Basalmembranen der Glomeruluskapillaren ergab daß diese mit steigendem Alter zunimmt und daß diese Verdickung bei diabetischen Tieren möglicherweise beschleunigt verläuft. In den Tubuli derselben diabetischen Tiere wurde eine charakteristische segmentäre Verteilung der Glykogenspeicherung beobachtet, dabei schwankte aber die Intensität der Glykogenspeicherung auch innerhalb eines Segments von Zelle zu Zelle. Das auffallendste im Zusammenhang mit der Glykogenspeicherung beobachtete Phänomen waren mit Glykogen angefüllte Lysosomen. Wie es zu dieser lysosomialen Glykogenspeicherung kommt, ist noch unbekannt; der erhöhte Anfall von Glucose (Reabsorption) und/oder eine durch den Diabetes bedingte Störung lysosomialer Funktionen kommen als ursächliche Faktoren in Frage.

Key-words: Spontaneous diabetes, spiny mice, Acomys cahirinus, kidney, glomerulus, basement membrane, mesangium, tubulus, glycogen nephrosis, glycogen body, lysosome, diábetic nephropathy, collagen fibers, electron microscopy. 
In previous reports on our colony of spiny mice, we have considered the possibility that abnormal thickening of glomerular eapillary basement membranes might represent an alteration characteristic of spontaneous hyperglycemia in these animals [20]. More extensive studies have subsequently indicated that a progressive thickening of capillary basement membranes also occurs with age and in the absence of hyperglycemia [39]. The present report concerns a systematic electron microscopic study of glomerular capillaries of normoglycemic and diabetic spiny mice and relates capillary basement width to the age of the animals and to the duration of hyperglycemia. In addition, glycogen nephrosis, a typical feature of the diabetic syndrome of spiny mice, was studied in some detail as to the morphological manifestations of tubular glycogenic infiltration.

\section{Material and Methods}

The spiny mice used originated from our colony of spiny mice which has been described in detail elsewhere $[20,13,21]$. They were fed a commercial preparation of laboratory chow (Altromin, R. Kunath S. A., Aarau, Switzerland), supplemented with a mixture of seeds.

The metabolic state of each animal was defined as to glycosuria and ketonuria during life [21] and as to plasma glucose, plasma immunoreactive insulin (IRI) concentration as well as pancreatic IRI content at death. These metabolic data have been published elsewhere $[21,40]$ and will only be referred to in the legends to the figures in order to characterize the metabolic state corresponding to each morphological observation. 36 normoglycemic and 14 hyperglycemic animals aged between 3 and 36 months were included in this study.

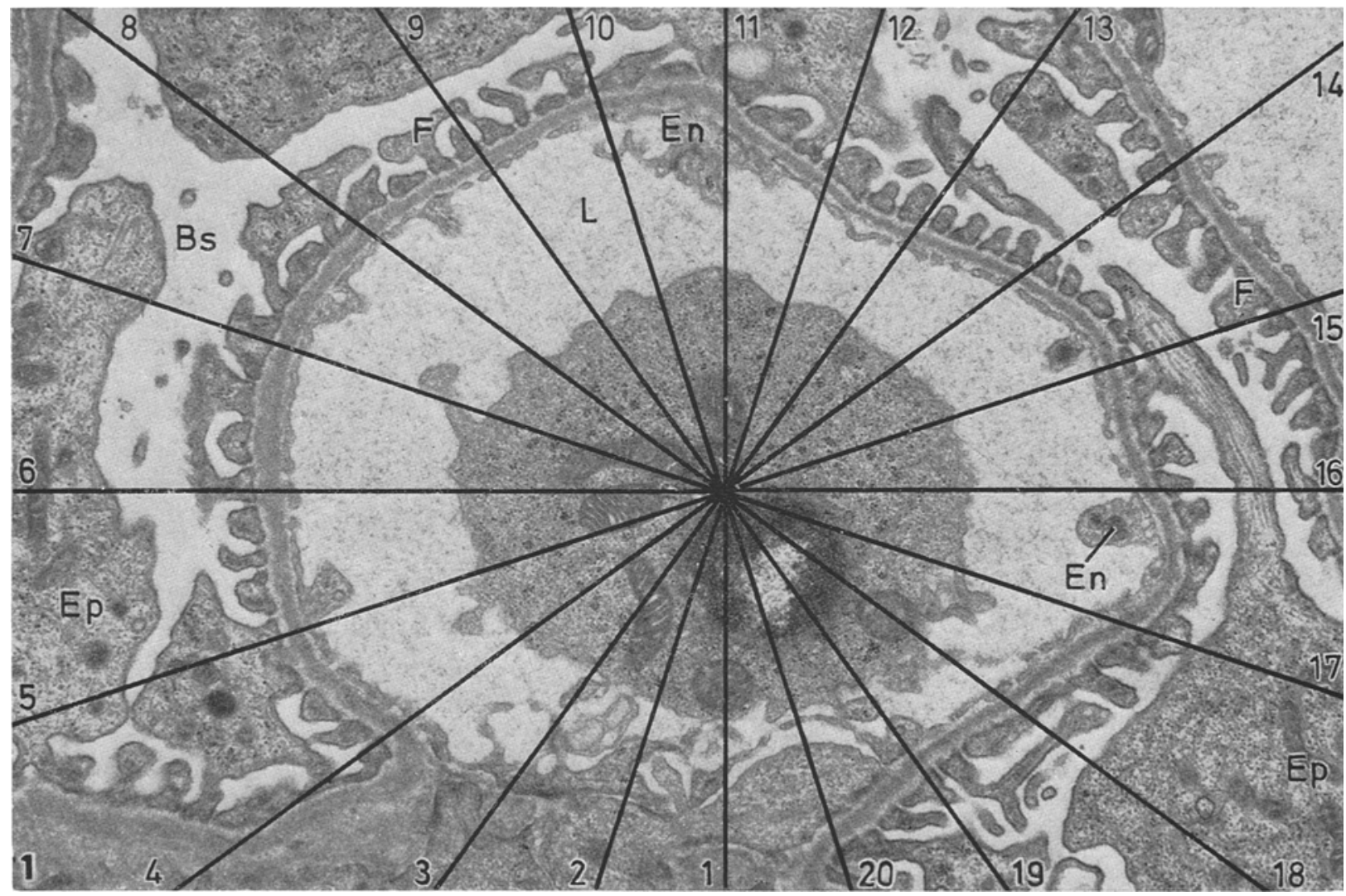

Fig. 1. 3 months old normoglycemic spiny mouse. Glomerular capillary overlaid with 20 equidistant radiating lines to illustrate the method used for quantitating basement membrane width [36]. The capillary basement membrane displays the well-known inner and outer layers of low electron density and a single central zone. Measurements were performed on the latter only. ( $\times 15150)$. Mean basement membrane width of this particular animal: $1250 \AA$

$\mathrm{BB}=$ brush border

$\mathrm{bm}=$ basement membrane

Bs = Bowman's space

$\mathrm{C}=$ peritubular capillary

$\mathrm{CR}=$ ciliary rootlet

c = centriole

En = endothelium

$\mathrm{Ep}=$ visceral epithelial cell
Key to abbreviations used in electronmierographs

$\begin{array}{ll}\text { er } & =\text { rough endoplasmic reticulum } \\ \mathrm{F} & =\text { foot process } \\ \mathrm{G} & =\text { Golgi complex } \\ \mathrm{G} 1 & =\text { Glycogen } \\ \mathrm{L} & =\text { glomerular capillary lumen } \\ \mathrm{I} & =\text { lipid droplet } \\ \mathrm{Ly} & =\text { Iysosome } \\ \mathrm{m} & =\text { mitochondrion }\end{array}$

$\mathrm{mb}=$ multivesicular body

$\mathrm{mp}=$ cytoplastic process of the mesangial cell

$\mathrm{Mc}=$ mesangial cell

$\mathrm{mm}=$ mesangial matrix

$\mathrm{N}=$ nucleus

$\mathrm{RBC}=$ red blood cell

$\mathrm{Tl}=$ tubular lumen 
The animals were stunned by a blow on the head and bled after cutting of the throat with a razor blade. Small pieces of tissue destined for the measurement of basement membrane width were immediately removed and fixed in ice-cold $2 \%$ osmium tetroxide [29]. Other pieces were fixed in 4\% glutaraldehyde (phosphatebuffered) and $2 \%$ osmium tetroxide. All samples were dehydrated in alcohol and embedded in Epon [28]. Semi-thin sections of kidney were cut with a PorterBlum microtome and either stained with toluidine blue or directly examined with the phase-contrast microscope. Thin sections were prepared with the LKB ultramicrotome, stained with uranyl acetate and lead hydroxide [22] and studied with Zeiss EM-9 and Philips300 electron microscopes. Glomerular capillary basement membrane width was measured on micrographs random as first encountered; thus, for any animal, a total of approximately 250 measurements was obtained from 15 glomerular capillaries. The mean of the 15 measurements represents the "glomerular capillary basement membrane thickness" of a given animal. Comparisons between animals, or groups of animals, and the statistical evaluation by Stutent's t-test were based on these means for each individual animal.

\section{Results}

\section{Glomerular changes}

a) Normoglycemic animals: the basement membranes of the glomerular capillaries of young animals were of very even thickness (Fig. 1). The latter increases with age, but varies considerably between dif-

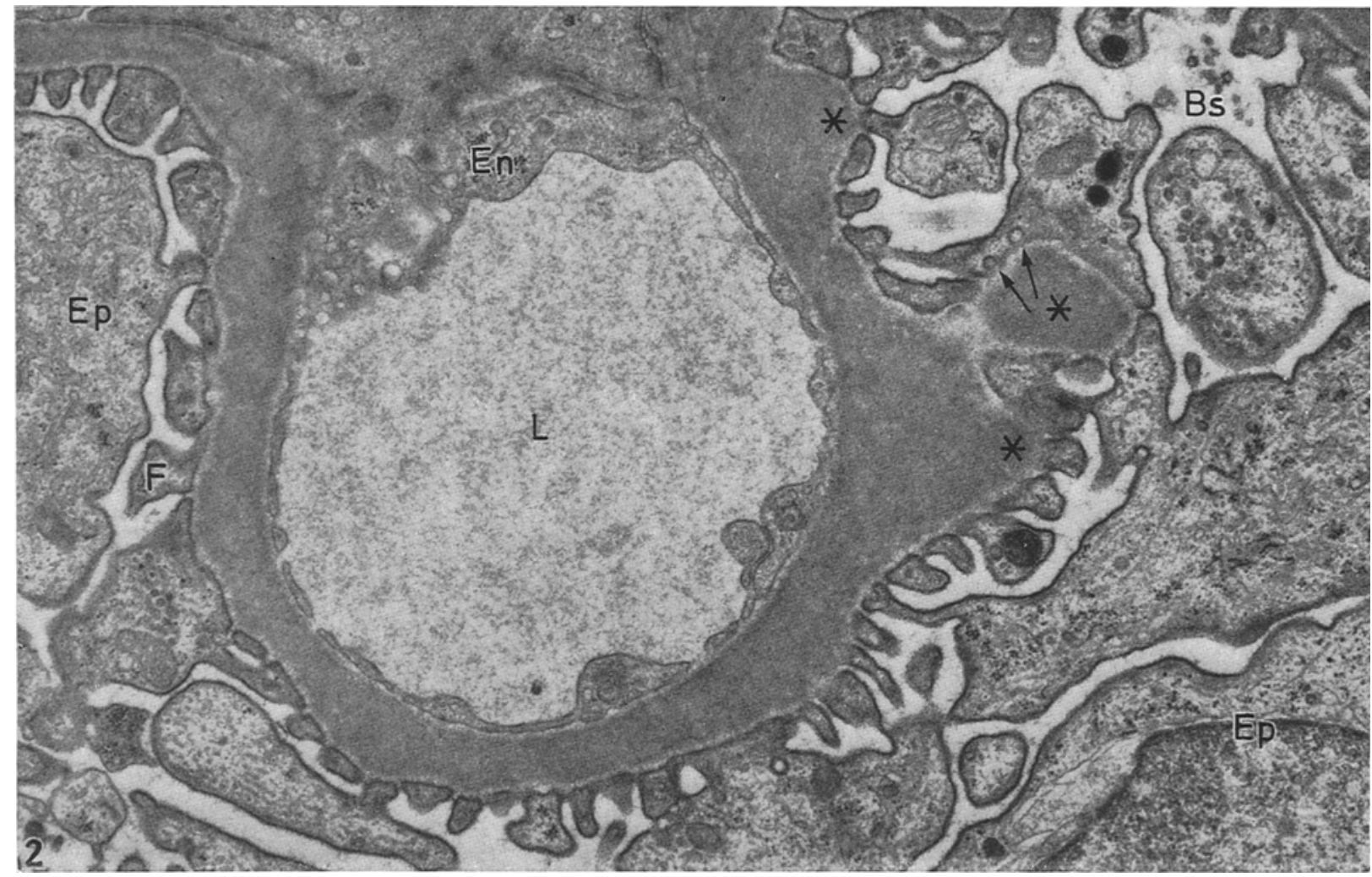

Fig. 2. 28 months old normoglycemic spiny mouse. Mean basement membrane width: 5800 A. Some irregularities can be recognized on the epithelial side of the basement membrane (*). The arrows point to two images suggestive of pinocytosis. $(\times 15150)$

(X 5050) obtained with the Philips-300 electron microscope and enlarged to a final magnification of X 15,150 . Measurements were performed using a radial measur. ing grid as described by Siperstein et al. [36], and detailed in the legend to Fig. 1. The axial regions near the mesangium as well as evident tangential cuts were excluded. For each animal, five open, transversally-sectioned capillaries of three different glomeruli were studied, both glomeruli and capillaries being chosen at ferent capillary loops of the same glomerulus (Fig. 2). In addition to this more regular increase in the diameter, focal thickening of the capillary basement membrane occurred on its epithelial side, where it often appeared as hemispherical protuberances which were structurally indistinguishable from the material constituting the basement membrane (Figs. 2,3). With increasing age, these areas of micro-nodular thickening increased both in number and size. 

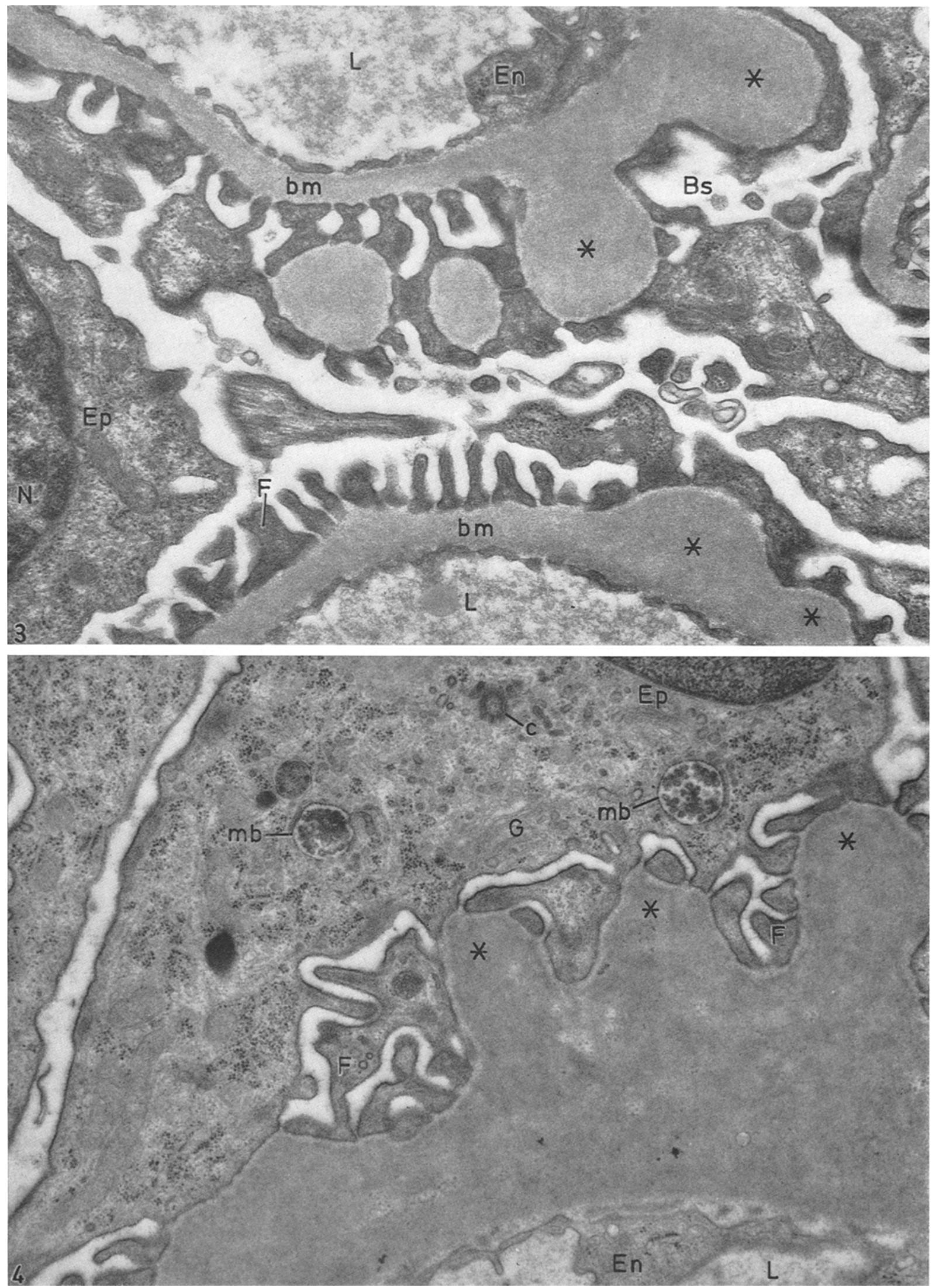
In addition to the thickening of the capillary basement membranes, important age-dependent alterations were observed in the mesangial region. In young animals (Fig. 6), the mesangial matrix was scant and the mesangial cells could easily be recognized. In older animals, the matrix occupied increasing portions of the mesangial area and recognizable mesangial cytoplasm was reduced to projections between "Iakes" of mesangial matrix. The cells themselves were separated by large areas occupied by mesangial matrix which was structurally indistinguishable from the material constituting the capillary basement membrane (Fig. 7).

Another alteration of the mesangial region, apparently also related to age, was the oecurrence of electronlucent areas containing collagen fibers (Figs. 9, 10). Such structures were not seen in kidneys of young animals but frequently in those of animals beyond the age of 12 months.

b) Diabetic animals: As indicated in Figs. 4, 5, and 8 , the morphological changes of the glomerular capillary basement membrane and of the mesangial region seen in diabetic animals were qualitatively similar to those seemingly associated with ageing in the normoglycemic ones.

The results of the quantitative assessment of the thickness of the glomerular capillary basement membranes of non-diabetic and diabetic animals of different ages are'summarized in Fig. 11. A progressive, agedependent increase in the thickness of the basement membrane is observed in non-diabetic animals. In each age group, the greatest capillary basement membrane diameter was encountered in a diabetic animal; however, measurements made in other diabetic animals, especially in young ones, yielded results well within the normal range.

\section{T'ubular alterations related to the deposition of gly- cogen}

In hyperglycemic animals (plasma- or serum-glucose above $350 \mathrm{mg} / 100 \mathrm{ml}$ ), glycogen infiltration of tubular epithelial cells was regularly observed. It showed a characteristic pattern of segmental distribution in that the terminal straight segment of the proximal tubule was but rarely affected (Fig. 12) while the cells of the loop of Henle, the distal tubules and the cortical collecting ducts were frequently seen to contain large amounts of glycogen (Figs. 13, 14, 15). In contrast to this, the section of the proximal convoluted tubule closest to the glomerulus was regularly free of glycogen.

Fig. 3. 28 months old normoglycemic spiny mouse. Several sites of nodular thickening are seen on the epithelial side of the basement membrane $(*)$. Fixation with glutaraldehyde, post-fixation with osmium tetroxide. $(\times 20000)$

Fig. 4.7 months old ketotic diabetic spiny mouse. Duration of diabetes: 3 months. Plasma glucose at death 400 $\mathrm{mg} / 100 \mathrm{ml}$. Grossly thickened basement membrane with three sites of focal thickening expanding into adjacent epithelium. $(\times 20000)$
Within a given segment, the degree of glycogen infiltration varied considerably from cell to cell. The qualitative aspect of glycogen infiltration, however, was uniform in all segments, in that glycogen was present in its monoparticulate form ( $\beta$-particles of Drochmans [10]). The individual glyeogen particles were disseminated throughout the cytoplasm (Fig. 12) or grouped and tightly packed, either focally in small areas or in compact aggregations occupying large portions of the cytoplasm (Figs. 13, 14, 15). In cells loaded with glycogen, only a thin cytoplasmic area around the nucleus, the Golgi complex and along th plasma membrane remained free of glycogen. Intranuclear glycogen was not encountered.

The most striking aspect of glycogen infiltration was the occurrence of round, single-membrane-lined bodies filled with glycogen particles (Fig. 16). Apart from glycogen, they contained inclusions which morphologically characterized them as lysosomes. Some cells contained a large number of such lytic bodies (Figs. 16, 17), which were observed to vary considerably in size, as indicated by the "giant lysosome" represented in Fig. 16. Apart from these lysosomes which contained glycogen only, some cells also included typical autophagosomes (Figs. 18, 19) which, in addition to glycogen, contained membranous structures and mitochondria (Fig. 19).

\section{Discussion}

Intercapillary glomerulosclerosis with thickening of the basement membrane of the glomerular capillaries is now considered a characteristic feature of the normal process of ageing $[2,3,16,14,25,15]$. The present study in spiny mice, in which a quantitative assessment of the increase in capillary basement membrane thickness was attempted, confirms this notion and corroborates our earlier observations for which no quantitative measurements were available [39]. The mechanisms responsible for this progressive, age-dependent increase in basement membrane thickness and for the deposition of basement membrane-like material around the mesangial cells are still unknown. Since both the mode of synthesis and of disposal of basement membrane matarial as well as their respective regulation are still poorly understood, it is currently impossible to go beyond the simple postulate of an imbalance between these two processes, resulting in the progressive accumulation of such material with increasing age.

The two principal features which we have observed in association with ageing were, first, the multiple focal protuberances which appear with increasing frequency on the epithelial side of the basement membrane and, secondly, the occurrence of collagen fibers in the midst of regions otherwise completely occupied by the basement membrane-like material of the mesangial matrix.

The formation of nodules on the epithelial side of glomerular basement membranes and their more frequent occurrence in older individuals has previously 


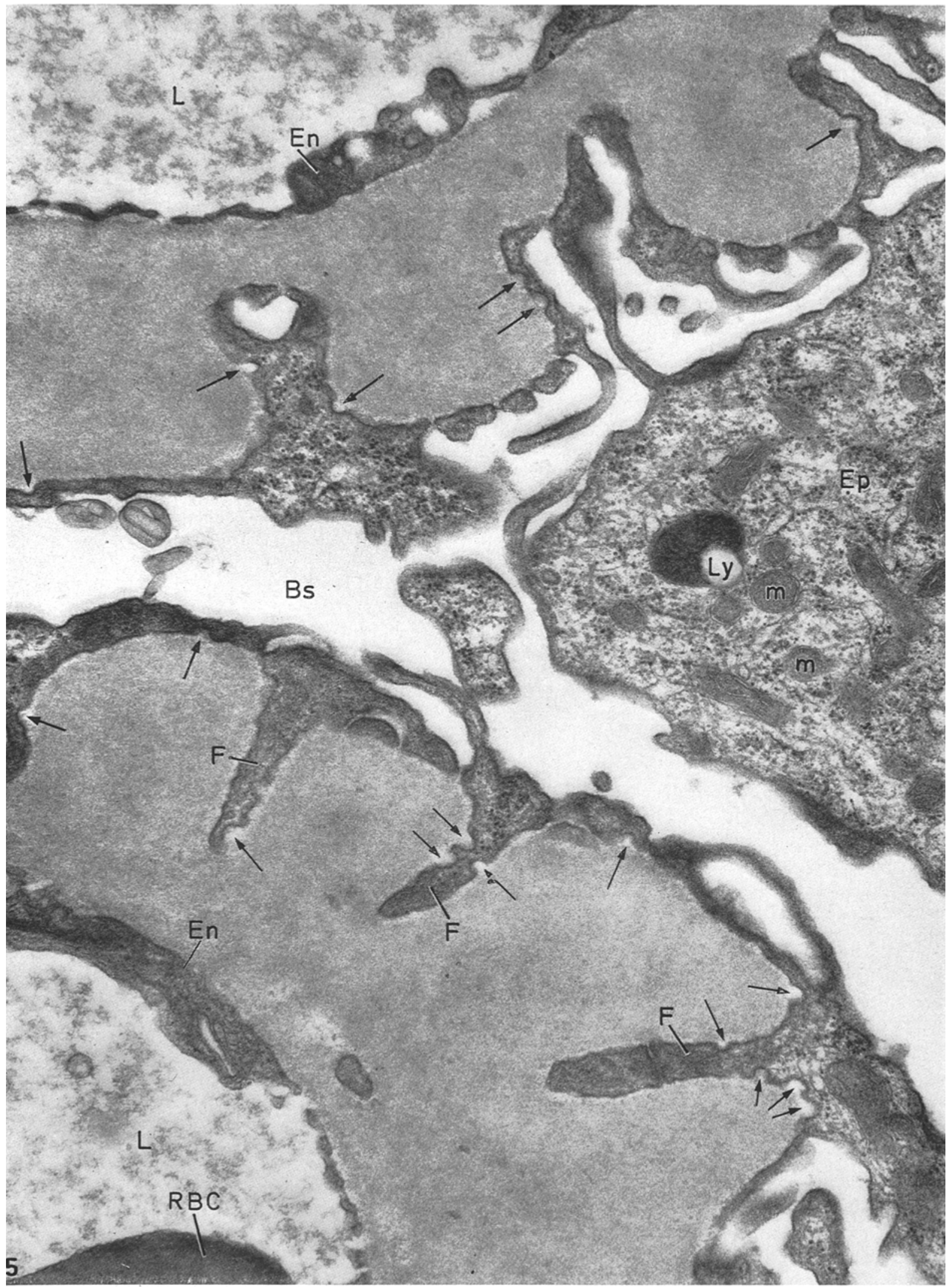


been observed both in apparently healthy humans and in non-diabetic experimental animals $[9,19,35,8]$. Although it is firmly established that the material forming the glomerular capillary basement membrane is the product of the epithelial cell [26], it is unknown how such localized accumulations come about. The observation of figures suggestive of pinocytosis in the plasma membrane of adjacent foot processes, while possibly indicative of an increased turnover of components of the hemispherical protrusions, does not allow the conclusion of either excessive production or absolutely or relatively deficient removal of basement membrane material at these sites.

In spiny mice, we have never as yet seen the lesions considered to be "specific" for diabetes, such as nodules of Kimmelstiel-Wilson [24]. This may be related to the rather short duration of the disease. Indeed, the present

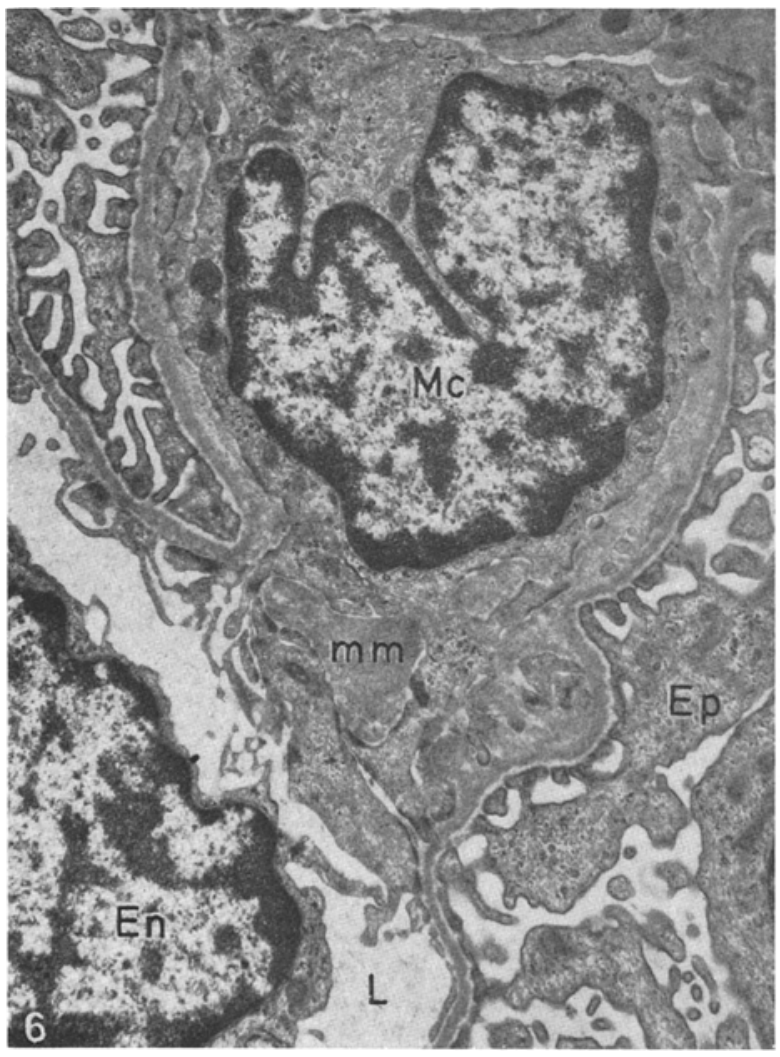

Fig. 6. Same animal as Fig.1. Mesangial region with a mesangial cell (Mc) surrounded by small amounts of mesangial matrix. ( $\times 11700)$

Fig. 5. 11 months old ketotic spiny mouse. Duration of diabetes: 3 months. Plasma glucose at death $480 \mathrm{mg} / 100$ $\mathrm{ml}$. Prominence of numerous sites of focal thickening on the epithelial side of the basement membrane. The plasma membranes of the adjacent foot processes exhibit images suggestive of the formation of pinocytotic vesicles. Fixation with glutaraldehyde, post-fixation with osmium tetroxide $(\times 27600)$ data (Fig. 11) do not establish with certainty whether or not diabetes affects the glomerular capillary basement membrane and the mesangial region. They do suggest, however, that the diabetic state may accelerate the age-dependent increase in deposition of basement membrane in the periphery of the glomeruli and of basement membrane-like material in the mesangial region. Although we are unable to present direct evidence which would allow us to rule out the hypothesis that the alterations we have observed might result from the deposition of an antigen-antibody complex involving insulin and antibodies formed against it [7], the observation that the lesions of our diabetic animals appear to differ from those occurring in non-diabetic animals in degree rather than in kind, does not favor this hypothesis. Alternatively, it might be assumed that all our spiny mice are "potential" or "latent" diabetics

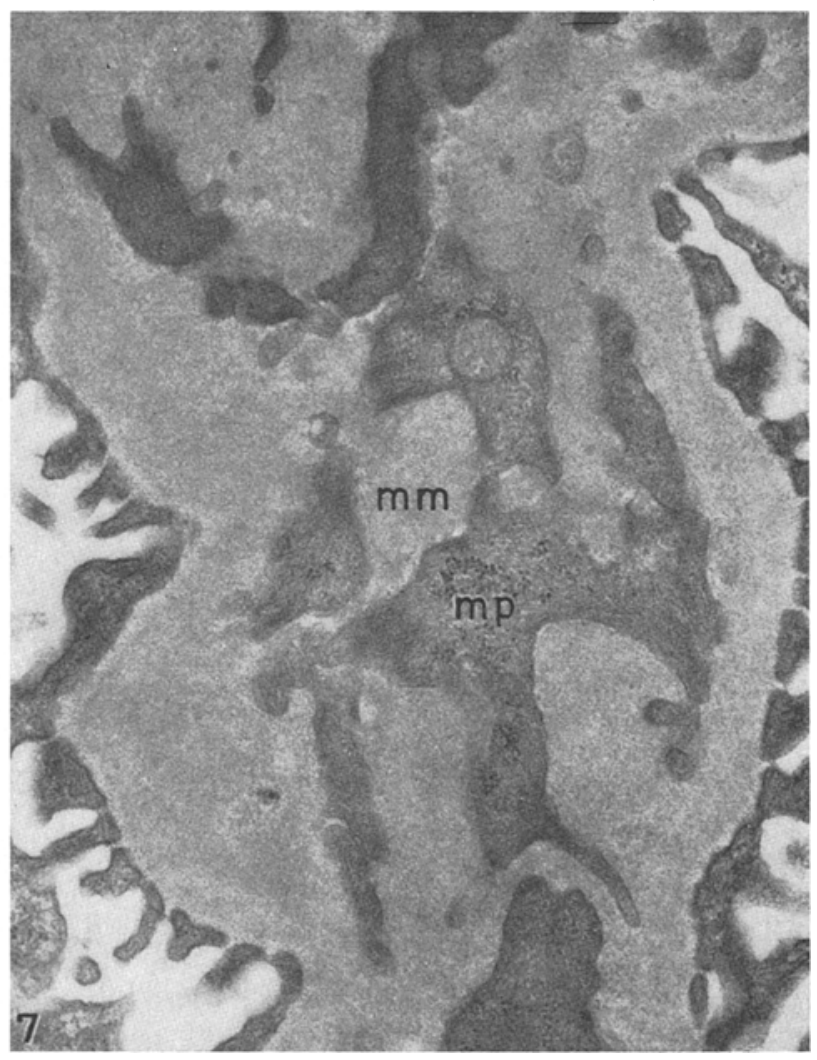

Fig. 7. 28 months old normoglycemic spiny mouse. Mesangial region. Large amounts of mesangial matrix engulf cytoplasmic processes (mp) of the mesangial cells. Fixation with glutaraldehyde, post-fixation with osmium tetroxide. $(\times 21000)$

or then, that the formation of such antigen-antibody complexes and their deposition in glomerular structures may not be specifically related to diabetes [15].

It would appear that collagen fibers are a normal constituent of the mesangial region of the kidney of older spiny mice. Indeed, we have found them - though 
often only after careful search - in the kidney of all older (more than 12 months) animals that we have thus far studied. Although the occurrence of collagen fibers in the kidney has been described both after specific experimental treatments and, less frequently, in normal animals $[5,43,27,30]$, available information is insufficient to establish with certainty whether the apparently regular occurrence of such structures in the kidney of older spiny mice is specific for our strain of this species or whether it represents a normal feature of ageing in other strains or species as well.

In view of the well established close chemical and structural relationship between collagen and the base-

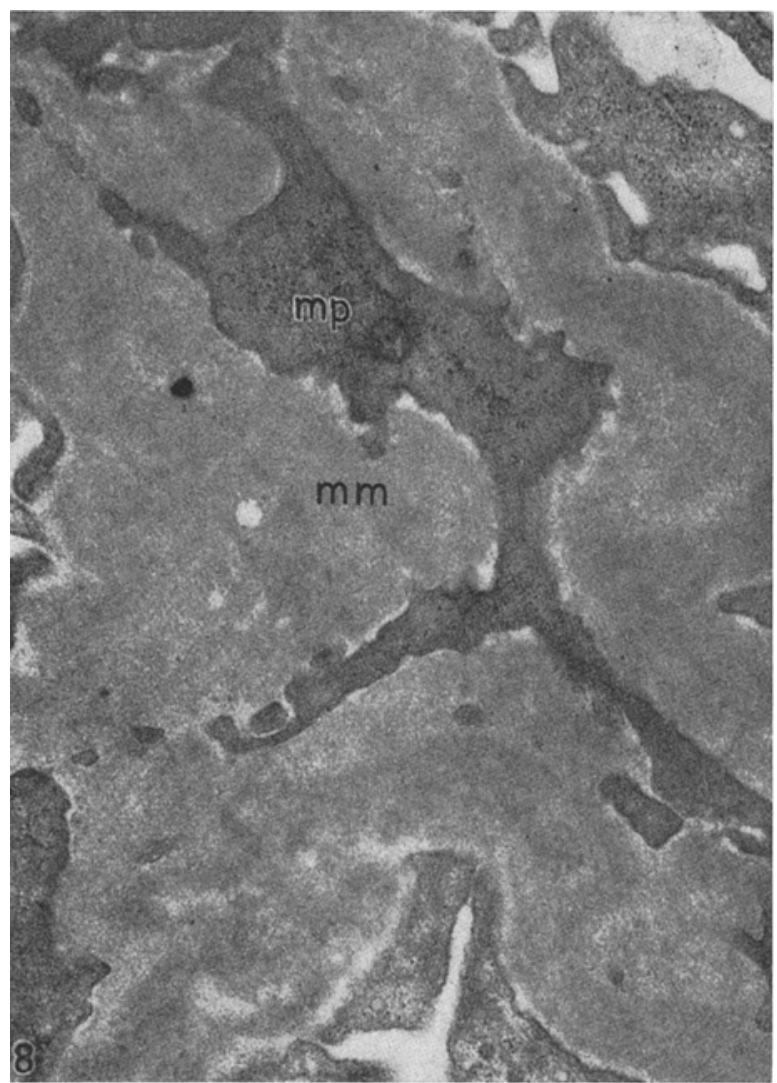

Fig. 8. Same animal as Fig. 4. Mesangial region. The increase in the amount of mesangial matrix is comparable to that shown in Fig. 7. Fixation with glutaraldehyde, post-fixation with osmium tetroxide. $(\times 20000)$

ment membrane material [38], the finding that collagen fibers are located in electronlucent areas surrounded by basement membrane-like mesangial matrix might indicate that they arise directly from the latter through locally occurring changes in its physico-chemical state. However, although the compositional differences between basement membrane glycoproteins and of collagen concern principally the carbohydrate moiety, it is not known whether complex structures such as glycoproteins are interconvertible once they have left the site of synthesis, i. e. the rough endoplasmic reticulum

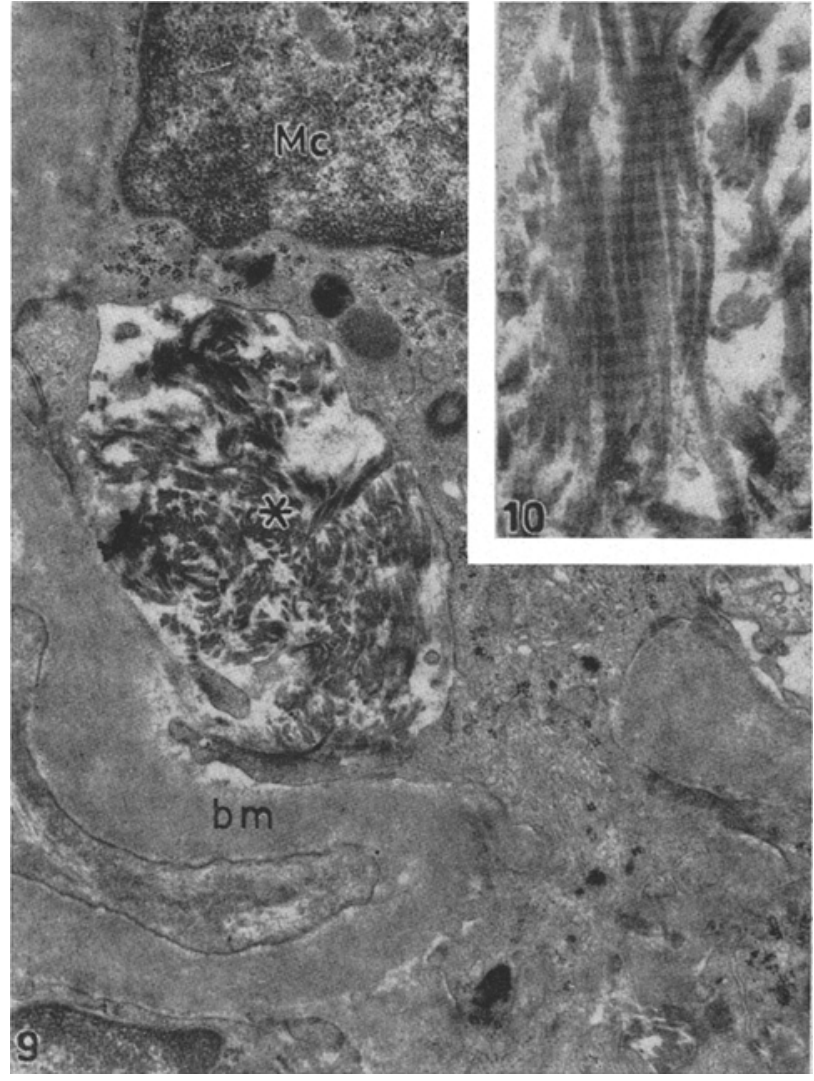

Fig. 9. 15 month old normoglycemic spiny mouse. Bundles of collagen fibers within an electronlucent area surrounded on one side by a mesangial cell (Mc) and by a basement membrane on the other. $(\times 14000)$. The insert (Fig. 10) illustrates the periodicity of collagen. $(\times 28200)$

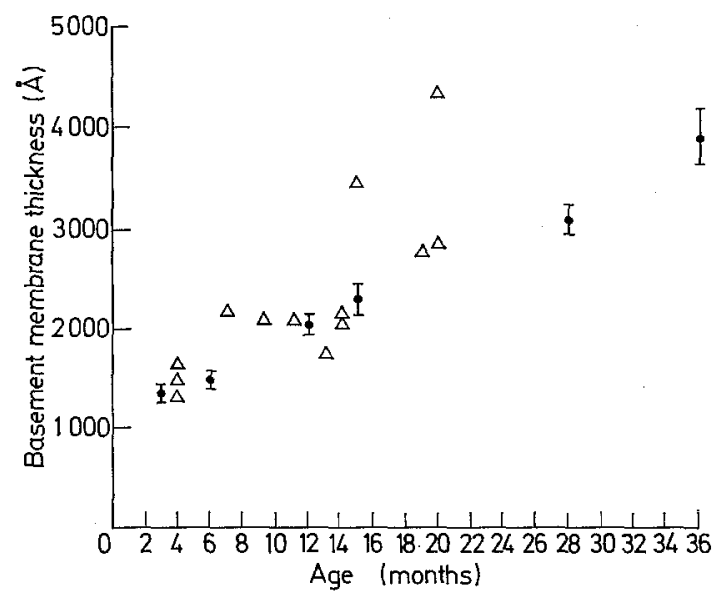

Fig. 11. Thickness of glomerular capillary basement membrane of normoglycemic and diabetic spiny mice of varying age. For technical details see "Material and Methods". Dots indicate means obtained in groups of normoglycenic animals of equal age $(n=6$ per age group $) \pm$ S.E.M. triangles represent individual diabetic animals killed at the age indicated. Values obtained in normoglycemic animals above the age of 6 months differ significantly $(p<$ 0.01 ) from those obtained in 3 and 6 months old ones. Values for 28 and 36 months old animals differ signifcantly from those of 15 months old ones $(p<0.01)$ 
and the Golgi complex of the epithelial cell. On the other hand, what appears to be typical collagen fibers might also represent an altered state of aggregation of glycoproteins closely related to but not identical with collagen [23] or, alternately, that the basement membrane-like material consists of glycoproteins normally associated with collagen [1].

Glycogen storage in cells lining the renal tubules occurs under various physiological, pathological and experimental conditions, and its morphological and histochemical manifestations have been described and extensively reviewed $[37,6]$.

In general, the fine structure of the cytoplasmic organelles of tubular cells loaded with glycogen remains unaltered. The accumulation of glycogen is, therefore, considered the consequence of excessive reabsorption of glucose rather than the expression of cellular degeneration. Indeed, and in agreement with observations made by others $[6,41,34,33,11]$, the extent of glycogenic infiltration observed in our animals appeared to correlate with the degree of hyperglycemia and glycosuria. A puzzling but unquestioned finding is that of considerable differences in the degree of glycogen infiltration which were observed between individual cells of a given tubular segment though it is likely that neighbouring cells were exposed to the same metabolic environment both on their tissular and their luminar surfaces. Similar observations have been made in relation with glycogen storage in B-cells of the pancreas of spiny mice [32] and it is conceivable that such differences in the degree of glycogen infiltration reflect otherwise not apparent differences in the functional state of individual cells.

The most impressive finding was that of singlemembrane-lined, glycogen-containing round bodies which apparently represent lysosomes. Although comparable pictures have been observed in liver and kidney of patients with Pompe's disease (type II glycogenosis) $[4,42,12]$ and in the livers of metabolically normal newborn rats and mice $[18,31]$, they have thus far and to the knowledge of the authors not been described in tissues of diabetic organisms. The presence of acid phosphatase in analogous structures occurring both in Pompe's disease and newborn rats $[12,31]$ lends as yet indirect support to the contention that the round bodies we have observed in the tubular cells of our animals represent lysosomes.

The mechanisms responsible for the accumulation of glycogen in lysosomes remain unknown. In Pompe's disease, the lack of lysosomal acid $\alpha$-glucosidase has been put forward as causative factor [17] and glycogen storage may therefore, in this instance, reflect a primary defect of lysosomal function. In newborn rats and mice [18, 31], it could result from a transient and physiological deficiency in glycogenolytic enzymes; however, the possibility of relative lysosomal insufficiency in the face of accelerated glycogen turnover in the postnatal period has not been ruled out conclusively. Similarly, the available data do not as yet allow us to attribute the occurrence of glycogen-containing round bodies in renal tubular cells of diabetic spiny mice to either absolute or relative impairment of lysosomal function. Indeed, although renal reabsorption of glucose is certainly increased in these glycosuric and/or hyperglycemic animals, intracellular disposal of glycogen could be impaired in diabetes, even in cells with an insulin-insensitive glucose transport system.

Acknowledgements. The authors are indebted to Mrs. Marthe Sidler-Ansermet and Miss Charlotte Hedinger for their expert technical help and unfailing interest and enthusiasm.

\section{References}

1. Alousi, M.A., Post, R. S., Heymann, W. : Experimental autoimmune nephrosis in rats. Amer. J. Path. 54, $47-71(1969)$

2. Andrew, W., Pruett, D.: Senile changes in the kidneys of Wistar Institute rats. Amer. J. Anat. 100, 51-69 (1957).

3. Ashworth, C.T., Erdmann, R.R., Arnold, N.J.: Age changes in the renal basement membrane in rats. Amer. J. Path. 36, 165-179 (1960).

4. Baudhuin, P., Hers, H. G., Loeb, H.: An electron microscopic and biochemical study of type II glycogenosis. Lab. Invest. 13, $1139-1152$ (1964).

5. Bencosme, S.A., Stone, R.S., Latta, H., Madden, S. C.: Acute reactions with collagen production in renal glomeruli of rats as studied electron microscopically. J. Ultrastructure Res. 3, 171-185 (1959).

6. Biava, C., Grossman, A., West, M.: Ultrastructural observations on renal glycogen in normal and pathologic human kidneys. Lab. Invest. 15, 330-356 (1966).

7. Blumenthal, H.T., Hirata, Y., Owens, C.T., Berns, A. W.: A histo- and immunologic analysis of the small vessel lesion of diabetes in the human and in the rabbit. In: Small blood vessel involvement in diabetes mellitus, p. 279 - 287, Siperstein, M. A. (Ed.). Washington, D.C.: Am. Inst. Biological Sciences 1964.

8. Comerford, F. R., Cohen, A.S., Desai, R. G.: The evolution of the glomerular lesion in NZB mice. Lab. Invest. 19, 643-651 (1968).

9. Coulfield, J.B. : cited by [8].

10. Drochmans, P.: Morphologie du glycogène. Etude au microscope électronique de colorations négatives du glycogène particulaire. J. Ultrastructure Research 6, $141-163$ (1962).

11. Froesch, E.R., Ashmore, J., Renold, A. E.: Comparison of renal and hepatic effects of fasting, cortisone administration and glucose infusion in normal and adrenalectomized rats. Endocrinology 62, 614-620 (1958)

12. Garancis, J.C.: Type II glycogenosis. Biochemical and electron microscopic study. Amer. J. Med. 44, 289300 (1968).

13. Gonet, A.E., Stauffacher, W., Pictet, R., Renold, A. E.: Obesity and diabetes mellitus with striking congenital hyperplasia of the islets of Langerhans in spiny mice (Acomys cahirinus). I. Histological findings and preliminary metabolic observations. Diabetologia 1, 162-171 (1965).

14. Gude, W.D., Upton, A.C.: A histologic study of spontaneous glomerular lesions in aging RF mice. Amer. J. Path. 40, 699-709 (1962).

15. Guttman, P.H., Andersen, A.C.: Progressive intercapillary glomerulosclerosis in aging and irradiated beagles. Radiat. Rues. 35, 45-60 (1968).

16. - Kohn, H.I.: Progressive intercapillary glomerulosclerosis in the mouse, rat and chinese hamster, associated with aging and X-ray exposure. Amer. J. Path. 37, 293-307 (1960). 

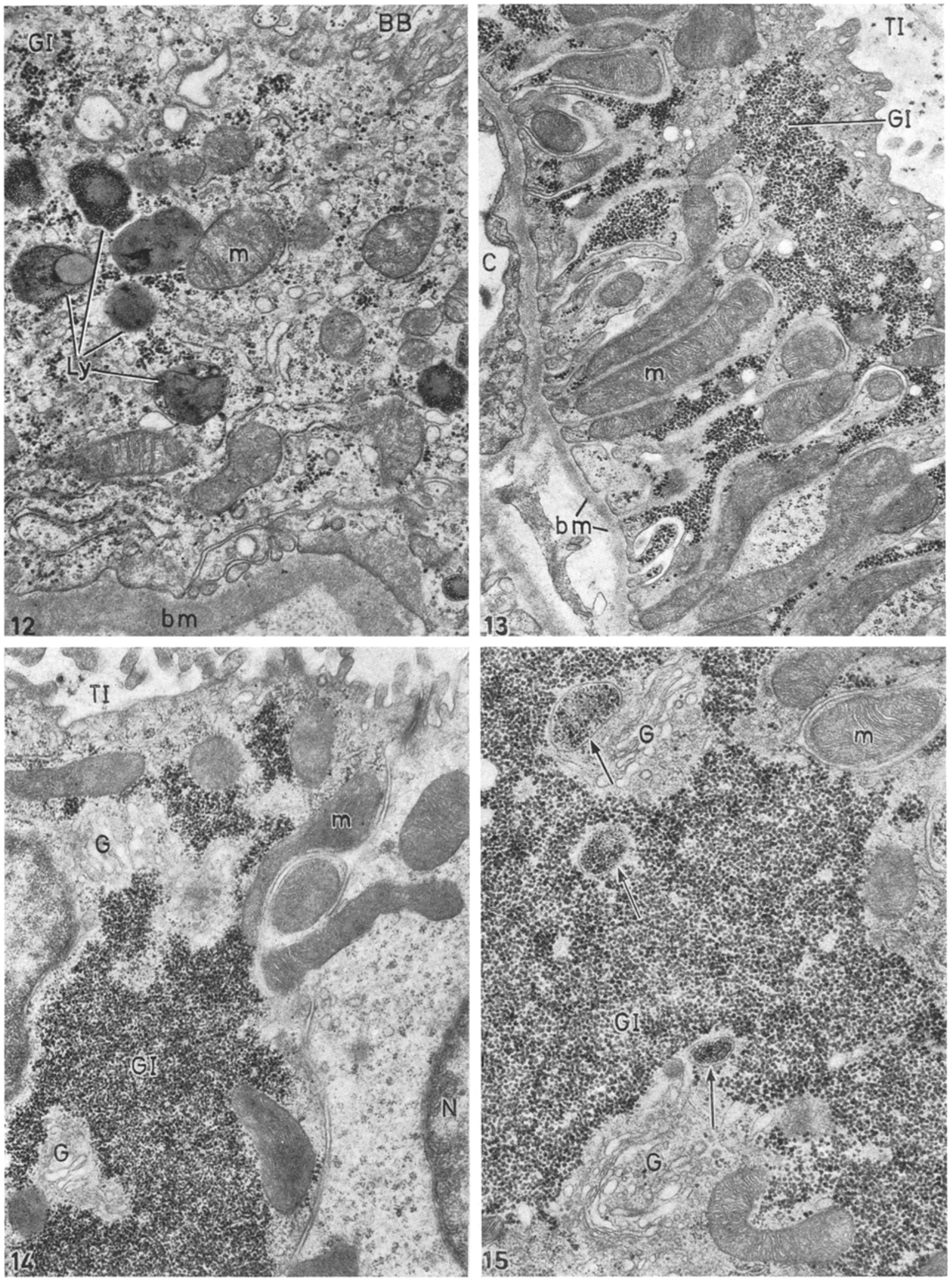
Fig. 12. 20 months old ketotic diabetic spiny mouse. Duration of diabetes: 15 months. Plasma glueose at death $400 \mathrm{mg} / 100 \mathrm{ml}$. Straight part of proximal tubule. Small groups of glycogen particles (Gl) scattered throughout the cytoplasm $(\times 18000)$

Fig. 13. Same animal as Fig. 12. Distal tubule. A large number of tightly packed glycogen particles occupy part of the cytoplasm. $(\times 13800)$

Fig. 14. 11 months old ketotic diabetic spiny mouse. Duration of diabetes: 3 months. Plasma glucose at death $480 \mathrm{mg} / 100 \mathrm{ml}$. Cortical collecting duct. The cell depicted on the left-hand side is packed with glycogen while that on the right-hand side contains none. By contrast, numerous polyribosomes are seen in its less electron-dense hyalo. plasm. Fixation with glutaraldehyde, post-fixation with osmium tetroxide

Fig. 15. Same animal as in Fig. 12 and 13. Part of a cell of a distal tubule. In spite of the abundance of glycogen in the cytoplasm, the Golgi complexes $(G)$ are consistently almost devoid of glycogen. Three merabrane-lined bodies filled with glycogen can be recognized in their proximity (arrows). $(\times 20400)$
19. Jørgensen, F.: Electron microscopic studies of normal glomerular basement membrane. Lab. Invest. 17, 416-424 (1967).

20. Junod, A., Orci, L., JRenold, A.E. : Lésions morphologiques et physiologiques dans le syndrome complexe des souris à piquants (Acomys cahirinus). In: Journées annuelles de diabétologie de l'Hôtel-Dieu, Paris, p. 31-39. Paris: Ed. Médicales Flammarion 1968.

21. - Letarte, J., Lambert, A. E., Stauffacher, W.: Studies in spiny mice (Acomys cahirinus): Metabolic state and pancreatic insulin release in vitro. Horm. Metab. Res. 1, 45-5̌2 (1969).

22. Karnovsky, M.J.: Simple methods for "staining with lead" at high $\mathrm{pH}$ in electron microscopy. J. biophys. biochem. Cytol. 11, 729-732 (1961).

23. Kefalides, N.A.: Characterization of the collagen from lens capsule and glomerular basement membranes. In: Diabetes, p. 307-322, J. Östman (Ed.). Amsterdam: Excerpta Medica Foundation 1969.

24. Kimmelstiel, P., Wilson, C.: Intercapillary lesions in the glomeruli of the kidney. Amer. J. Path. 12, 83-97 (1936).

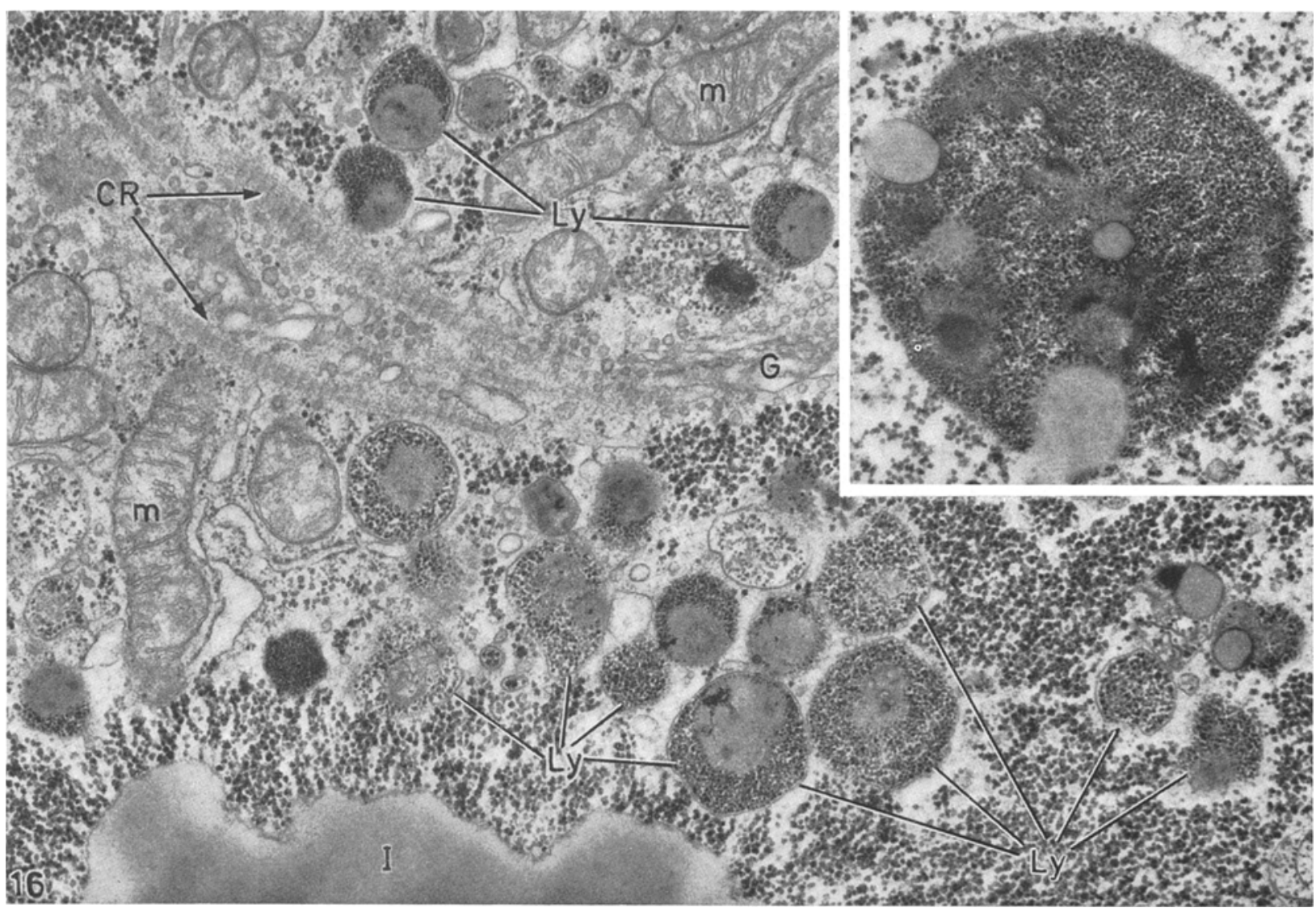

Fig. 16. Same animal as Fig. 14. Part of a cell of the straight part of a proximal tubule. Numerous glycogen-filled lysosomes $(\mathrm{Ly})$ of different size near the Golgi complex $(G) .(\times 22800)$.The insert shows a giant lysosome filled with glycogen. $(\times 18000)$

17. Hers, H. G.: Inborn lysosomal diseases. Gastroenterology 48,625-633 (1965).

18. Jézéquel, A.-M., Arakawa, K., Steiner, J.W.: The fine structure of the normal, neonatal mouse liver. Lab. Invest. 14, $1894-1930(1965)$.
25. Kohn, H.I., Guttman, P.H.: Life span, tumor incidence and intercapillary glomerulosclerosis in the chinese hamster (Cricetulus griseus) after whole-body and partial-body exposure to X-rays. Radiat. Res. 21, $622-643$ (1964). 


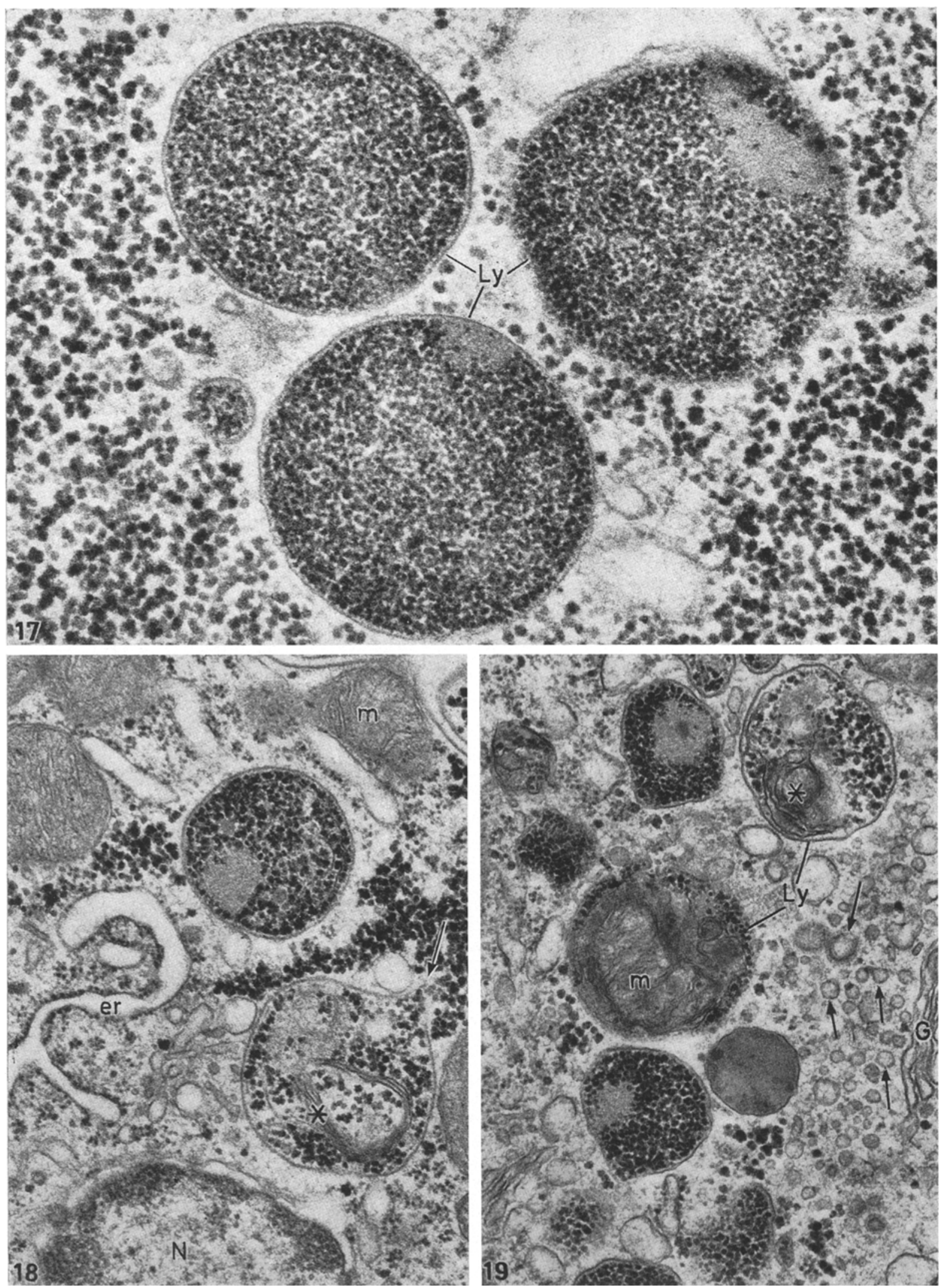


Fig. 17. 13 months old ketotic diabetic spiny mouse. Duration of diabetes: 3 months. Plasma glucose at death: $450 \mathrm{mg} / 100 \mathrm{ml}$. Cortical collecting duct. Three glycogenfilled lysosomes. The size of the glycogen particles within the lysosomes appears to be smaller than that of the particles surrounding them. The two lysosomes on the left-hand side are limited by well-defined membranes. $(\times 60600)$

Fig. 18. Same animal as Fig. 17. Straight part of proximal tubule. Part of a cell containing a well-defined glycogencontaining lysosome (top) and a body enclosing glycogen and membranous structures (*) and surrounded only in part by a membrane (arrow). This picture may represent a stage in the formation of an autophagosome. $(\times 39000)$

Fig 19. Same animal as Fig. 14. Straight part of proximal tubule. Two autophagosomes (Ly) which in addition to glycogen contain membranous structures (*) and a mitochondrion $(\mathrm{m})$. Arrows point to microvesicular structures associated with the Golgi complex. $(\times 38800)$

26. Kurz, S.M., Feldman, J.D.: Experimental studies on the formation of the glomerular basement membrane. J. Ultrastructure Res. 6, 19-27 (1962).

27. Latta, H. Collagen in normal rat glomeruli. J. Ultrastructure Res. 5, 364-373 (1961).

28. Luft, J.H.: Improvement in Epoxy-resin embedding methods. J. biophys. biochem. Cytol. 9, 409-414 (1961).

29. Millonig, G.: Advantages of a phosphate buffer for $\mathrm{OsO}_{4}$ solutions in fixation. J. appl. Physiol. 32, 1637 $-1640(1961)$.

30. Peach, R., Williams, G.: Collagen in normal mouse glomeruli. Nature 211, 1099 (1966).

31. Phillips, M.J., Unaker, N.J.: Glycogen depletion in the newborn rat liver. An electron microscopic and electron histochemical study. J. Ultrastructure Res. 18, $142-165(1967)$.

32. Pictet, R., Orci, L., Gonet, A.E., Rouiller, Ch., Renold, A. E.: Ultrastructural studies of the hyperplastic islets of Langerhans of spiny mice (Acomys cahirinus) before and during the development of hyperglycemia. Diabetologia 3, $188-211$ (1967)
33. Ritchie, S., Waugh, D.: The pathology of ArmanniEbstein diabetic nephropathy. Amer. J. Path. 33, $1035-1057$ (1957).

34. Robbins, S.L.: The reversibility of glycogen nephrosis in alloxan-treated diabetic rats. Amer. J. med. Sci. 219, $376-381$ (1950).

35. Shirai, T., Welsh, 3rd, G.W., Sims, E.A.H.: Diabetes mellitus in the chinese hamster. II. The evolution of renal glomerulopathy. Diabetologia $3,266-286$ (1967).

36. Siperstein, M.A., Unger, R.H., Madison, L.L.: Studies of muscle capillary basement membranes in normal subjects, diabetic and prediabetic patients. J. clin. Invest. 47, 1973-1999 (1968).

37. Spicer, S. S.: Histological localization of glycogen in the urinary tract and lung. J. Histochem. Cytochem. 6, $52-60(1958)$.

38. Spiro, R.G.: Glycoproteins: Biochemistry, biology and role in disease. New Engl. J. Med. 281, 991 - 1001, and $1043-1056(1969)$.

39. Stauffacher, W., Orci, L., Amherdt, M., Lambert, A.E., Renold, A.E., Rouiller, Ch.: Le diabète spontané chez l'animal: Considérations sur la pathogénèse du syndrome aigu et sur la morphologie des lésions du syndrome chronique. Pathologie et Biologie (Paris) 18, 539-549, $(1970)$.

40. - - Burr, I. M., Balant, L., Froesch, E.R., Renold, A. E.: Metabolic state, pancreatic insulin content and B-cell morphology of normoglycemic spiny mice (Acomys cahirinus) : Indications for an impairment of insulin secretion. Diabetologia, this issue.

41. Warren, S., Root, H.F.: The pathology of diabetes, with special reference to pancreatic regeneration. Amer. J. Path. 1, 415-429 (1925).

42. Witzleben, C.L. : Renal cortical tubular giyeogen localization in glycogenosis type II (Pompe's disease). Lab. Invest. 20, 424-429 (1969).

43. Yamada, E.: Collagen fibrils within the renal glomerulus. J. biophys. biochem. Cytol. 7, 407-409 (1960).

Dr. L. Orei

Institute of Histology and Embryology

University of Geneva

CH-1211 Geneva 4 